\title{
Familiarity and Trust: Explaining Trust in Government through Ethno-racial Differences
}

\author{
Eglė Vaidelytė \\ Kaunas University of Technology, \\ Donelaičio g. 73, LT-44249 Kaunas, Lithuania \\ Eglė Butkevičienè \\ Kaunas University of Technology, \\ Donelaičio g. 73, LT-44249 Kaunas, Lithuania \\ Vaidas Morkevičius \\ Kaunas University of Technology, \\ Donelaičio g. 73, LT-44249 Kaunas, Lithuania \\ Michiel S. de Vries \\ Radboud University Nijmegen, \\ Houtlaan 6525 XZ Nijmegen, The Netherlands

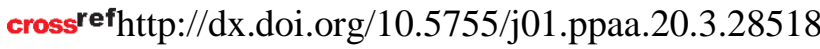

\begin{abstract}
The paper investigates whether generalized trust in government varies among ethnic groups in a society. Theories on trust predominantly explain such institutional trust by the capabilities and intentions of the trusted actors, and research into trust is mainly done at the individual level measuring whether individual characteristics of the trustee and trusted one has explanatory power. Meanwhile, this paper analyzes the institutional trust at the macro (country) level. Based on a comparative study among 27 countries, this paper argues that there are significant differences between ethnic groups regarding their trust in the country's government and that significant effects are visible with the country's income inequality and one of Hofstede's dimensions of national culture, namely 'power distance'. This is an important finding as it calls for multi-level analyses when explaining institutional trust. Trust is not only dependent on the individual characteristics of the trusted one and the trustee but also on macro-level variables.
\end{abstract}

Keywords: trust in government, ethnic groups, power distance, income inequality, International Social Survey Programme

Raktažodžiai: pasitikejjimas valdžia, etninès grupès, galios distancija, pajamų nelygybè, Tarptautine socialinio tyrimo programa

\section{Introduction}

In general, one would expect that the degree of trust in an actor is especially dependent on the acts and intentions of that actor to be trusted. However, there is also ample literature, which posits that trust is also (partly) based on familiarity between the trustee and the trusted one. This is especially expected for interpersonal trust, but it might also be the case for trust in public institutions. Being familiar with somebody, having the same background and sharing the same moral values might make one more trustful, as one can take the benevolence of the actions and intentions of the trusted one for granted (Uslaner, 2000). As one probably completely trusts oneself, a person might also be more inclined to trust people and institutions that in person's opinion are similar to her/him. As such, the ethno-racial background might be an essential factor in this respect, and there might be something like ethnicity or race-based trust (Smith, 2010). Investigating this type of trust is important, as many countries nowadays consist of a populace with multiple ethnic or/and racial backgrounds. This has even increased during the last decades because of globalization. What can we tell about the newcomers' trust in the government of the country they reside in, and would governments have more 
difficulties gaining their trust than the trust of their native citizens? This would be expected if familiarity does indeed impact trust in government. Therefore, our primary research question is whether different ethno-racial groups - particularly those occupying the dominant "majority" position within the polity and society and those occupying the "minority" position - differ in their trust in government. Secondly, we investigate whether cultural and socio-economic factors affect country level ethno-racial differences of governmental trust.

In order to answer this question, we first give a theoretical expose about the different conceptualizations of trust, describing what is theoretically known about the factors influencing trust and especially about the extent to which familiarity and ethno-racial background is expected to impact trust in government. This results in the hypothesis that people living in the same country but with different ethnic and/or racial backgrounds will show different levels of trust in the government of that country. The hypothesis is tested through a secondary analysis of the 2014 ISSP data on citizenship, a cross-national survey conducted in a large number of countries around the world and containing the necessary data to answer our research question. Further, we use cultural (Hofstede's cultural dimensions) and socio-economic indicators (Gini index and annual growth of GDP) for exploring explanatory factors.

\section{Theory}

In general, trust is defined in terms of capabilities - that the trusted one is able to do something and encapsulated interests - that the trusted one will act taking anothers' interests into account. Seligman (2000) defined trust as "some sort of belief in the goodwill of the other, given the opaqueness of other's intentions and calculations" (p. 43) while Russel Hardin (1999) defined it as the expectation of "encapsulated interest", that is, the knowledge that it is in the interest of the trusted to act on my behalf (Hardin cited by Warren, 1999, p. 24).

Trust is the key concept speaking about the quality of many societal issues - community, public governance, social welfare. As Uslaner (2000) notices, trust brings us a wide range of good things "from willingness to get involved in our communities to satisfaction with government performance, to making daily life more pleasant" (p. 569). As every widespread issue, trust is a multifaceted phenomenon that is not easy to define, which "appears to work somewhat mysteriously" (Uslaner, 2000 p. 569). Scholars have found that in societies where trust thrives, there is significantly more economic growth (Putnam, 1993; Whiteley, 2000; Zak and Knack, 2001; Beugelsdijk et al., 2004; Guiso et al., 2004). The reasons for this effect are that in high-trust societies, people are more likely to help each other (Coleman, 1990). Therefore, the trust could be seen as indicative of the strength of "social solidarity" in a country, which could affect government expenditures on education (Bjørnskov, 2012), and that trust affects the quality of governance, as it would lead to higher accountability (Putnam, 2000, p. 346; Nannicini et al., 2012), would help to bring about consensus, and would foster innovation (Knack and Zak, 2002). On the other hand, when some groups are left outside the society and feel to be at the "bottom of the economic ladder", it is usually hard to expect any kind of trust from them (Uslaner 2000). One could explain trust in three ways, namely the performance of the trusted one, characteristics of the trustee, and the relation between the trustee and the trusted one.

Trust is, first of all, related to the performance of the trusted one. It builds on the expectation that the future actions of the trusted one will be similar to those in the past, and if the trusted one performed well in the past and acted on the trustee's behalf, trust implies that we expect the trusted one will continue acting in such a way in the future. If this performance has been adequate in the eyes of the trustee, the trustee will tend to trust the trusted one to keep on doing a good job. If the trusted one fails, the trust gained will diminish. This is why trust in government declines during economic crises (Kroknes, Jakobsen \& Grønning, 2016; Wroe, 2015; Ananyev \& Guriev, 2014), and why trustlevels increase with an increase in national income (Brueckner, Chong and Gradstein, 2015; Anderson, 2015). Following Hardin (2000), trustworthiness, as a presumption of trust, is related to competence to perform and the motivation to perform on the trustee's behalf and refers to 
performance, competence and values simultaneously (p. 36). In this way, trust is encapsulated in the trustee's interest to fulfil the trust - citizens trust the government if they believe that it does share their concerns and interests and is capable to further their well-being (cf. De Vries \& Sobis, 2018).

Secondly, trust is based on the characteristics of the trustee. This reasoning is partly based on rational technical-economic reasoning and partly on social-psychological explanations. In terms of socio-economic circumstances, it has been found that people tend to be less trusting if they are poor (Chanley, Rudolph \& Rahn, 2000; Barth, 2016) and unemployed (Roth, Gross \& Novak-Lehmann, 2014). That is, if they personally experience the negative consequences of actions for which they believe the government is -at least partly - responsible, they will show less trust in the government. In terms of social psychological reasoning, trust and institutional confidence (or distrust and lack of confidence) are basic aspects of personality types. These explanations argue that "because of their psychological history and make-up, some individuals have an optimistic view of life and are willing to help others, cooperate, and trust and in the opposite, because of their own early life experiences, others are more pessimistic and misanthropic" (Newton and Norris, 2000). Following this way of thinking, "feelings of trust in others and optimism form a basic trust personality trait that is received in the first stage of psychological development" (Erikson, 1950 in Newton and Norris, 2000). SocialPsychological explanations identify trust as interpersonal (Rotter, 1988), social trust (Hardin, 2002), thin trust (Putnam, 2000), affective trust (Patterson, 1999), abstract trust (Paxton, 1999), generalized or general trust (Yamagishi, 2001; Smith, 2010).

The third explanation for the variance in trust-levels lies in the relation between the trustee and the trusted one and the extent to which they have shared values and a common lifestyle. In this reasoning, trust dwells on familiarity, a shared understanding of values and norms, in-group solidarity and collaborative culture. There is quite much empirical evidence that trust and collaborative culture have a strong, positive correlation (Kucharska, 2017). Kucharska (2017) emphasizes that her empirical study shows that "collaborative culture and trust occur together and strongly support each other" (p.72). Fukuyama (2001) defines the "radius of trust" as an outcome of in-group solidarity. He argues that "it appears to be a natural human proclivity for dividing the world into friends and enemies that is the basis of all politics" (p. 8). Fukuyama (2001) concludes that in-group solidarity produces a narrow radius of trust, which often imposes negative externalities on outsiders. Many authors (Uslaner, 2000; Fukuyama, 2001; Smith, 2010) presume that people are more likely to trust others like them - those of the same race, ethnicity, religion and class. It is widely noticed that in ethnically diverse neighbourhoods, people tend to trust less (Alesina and La Ferarra, 2002; Putnam, 2007; Smith, 2010). Smith (2010) argues that the key factors determining trust or distrust are ethno-racial and cultural socialization which refers to the experience which children gain from their parents about their ethnic heritage, cultural traditions and pride. Recent studies indicate that people tend to express greater trust in those they perceive to be like themselves (Smith, 2010, p. 463). As it was mentioned above, Newton and Norris (2000) emphasize the relevance of social-cultural settings for future trust. This line of reasoning fits into neo-institutional theory. Whereas classic institutional theories emphasize that political trust and distrust are rational responses by individuals to the performance of institutions (March, 1988; North, 1990), neo-institutional theories hypothesize that "sees human action as driven by rules of appropriate or exemplary behaviour, organized into institutions. Rules are followed because they are seen as natural, rightful, expected, and legitimate. Actors seek to fulfil the obligations encapsulated in a role, an identity, a membership in a political community or group, and the ethos, practices and expectations of its institutions" (March \& Olsen, 2004, p. 2). It is about behaviour especially determined by a logic of appropriateness, that is, shared internalized prescriptions of what is socially defined as normal, true, correct or good, without, or despite, calculation of consequences and expected utility, is of ancient origin. If the trustee and the trusted one have such shared prescriptions, trust is likely, and if not, such trust will be absent. Belonging to different ethnic groups might result in different cultural values, as distinguished by Hofstede (1984), where he distinguishes five and later six dimensions of culture, namely power-distance, individualism versus collectivism, femininity versus masculinity, uncertainty avoidance, and a short-versus long 
term orientation and, the one added later, indulgence versus restraint. This idea was supported by research done by Smith (2010). Smith (1997) concludes that representatives of minority groups demonstrate less trust than members of majority groups in society. Likewise, Uslaner (2000, p. 580) argues that minorities may believe that they share other values but be not confident that "others hold the same things dear as they do". Eventually, familiarity plays the key role in trusting and particularized, or strategic trust dominates among different ethnic groups.

In this context, the concepts of generalized, particularized and strategic trust should also be discussed. From the viewpoint of moral philosophy Uslaner (2000, p. 573) distinguishes strategic (based on experience and knowledge of others) and moralistic (unconditional or universal) trust, and, additionally, discusses generalized and particularized trust. Generalized trust is considered as the belief that most people can be trusted, and it leads to getting people into communities even if they have found some people less trustworthy. Meanwhile, particularized trust is "faith only in your kind", and unfamiliar people are suspect and presumed not to be trustworthy (Uslaner 2000, p. 573). Explanations for trust, dwelling on social and cultural settings reflect conceptualizations of particularized trust (Uslaner 2000) and assume that the ability to trust others and sustain cooperative relations is the product of common, social experiences and socialization, especially those found in the sorts of voluntary associations of modern society that bring different social types together to achieve a common goal (Norris and Newton, 2000). This group of trust explanations essentially argues that individual life situations and experiences unite "in group" members, creating social trust and cooperation, civic-mindedness, and reciprocity between individuals belonging to the in-group (Geertz, 1962; Ardener, 1964 in Newton and Norris, 2000, Williams, 1988). Therefore, people with different social and cultural backgrounds tend to distrust "out-group" individuals and communities (Smith, 2010). We extend these arguments and argue that not only social or individual trust is affected by social and cultural backgrounds. Political and institutional trust is strongly related to (if not determined by) social trust (Putnam, 1995; Hardin, 2000; Maloy, 2009) and, therefore, should also depend on the social and cultural background of trust conferring individual. Thus, our first hypothesis links ethno-racial background and trust in government:

H1. When an ethno-racial group is not represented in government, the effect thereof is that its members will show less trust in that government.

There are many studies exploring determinants of trust. However, little is known about the extent to which cultural factors impact the differences between ethnic and/or racial groups. Hofstede (2011), for example, distinguishes six cultural dimensions that characterize nations. However, each of the six could be a factor affecting differences within countries, namely, between ethnic and/or racial groups. Here it is assumed that ethno-racial differences of trust in government depend on national cultural institutions and especially on the strength of cultural dimensions in a country. If a country is known for its extreme femininity, this will have a significant effect on the differences between nationals and non-nationals, as these non-nationals might have a more masculine disposition. The same goes for values regarding power-distance, individualism, short or long-term orientation, uncertainty avoidance, and indulgence versus restraint. The reasoning is that ethnic minorities not used to taking risks and being risk avoidant might question the actions of a government in a society that is more prone to take risks. They might be doubtful about governments allowing people and media to question the actions of government if they come from a country in which the power distance is huge. They might be distrustful about public policies emphasizing individual responsibility instead of collectivism and might loath excessive public expenditures if they themselves are educated to show restraint. We hypothesize that differences in trust-levels between ethno-racial groups occur, especially in countries where such cultural values are extreme because in those cases, the potential shock perceived by those ethnic groups not belonging to the dominant group might be largest.

The above results in our second hypothesis:

H2. The prevalence and strength of the six cultural dimensions in a country, as distinguished by Hofstede, moderates the relationship between ethno-racial background and trust in government. 
Also, there is evidence that trust is related to socio-economic factors, especially economic wealth and socio-economic (in)equality. For example, Uslaner (2000) is analyzing trends of Americans' generalized trust, found that economic inequality is related to trust and that, in general, more egalitarian countries are more trusting (p. 587-589). The logic behind this relationship is relatively clear. Usually, ethno-racial minorities are less well-to-do in economic terms (Uslaner, 2000; Smith, 2010). Therefore, social inequality is complemented by economic inequality. Consequently, minorities might express less trust in government as they hold it accountable for the existing inequalities. Thus, in this paper, we investigate whether country-level ethno-racial differences of trust in government are related to economic inequality. On the other hand, the economic wealth of a country is related to trust levels and especially economic hardship produces distrust in public institutions (Uslaner 2000, Smith 2010). Here, again ethno-racial minorities usually are in a worse position compared to dominant groups, as economic downturns have more severe effects on communities, which are more fragile economically. Summarizing the above, we formulate our third hypothesis:

H3. The prevalence of economic hardship and socio-economic inequality in a country moderates the relationship between ethno-racial background and trust in government.

\section{Data and methods}

To test the above-mentioned hypotheses, we use data from the International Social Survey Programme (ISSP) module on citizenship (Citizenship II 2014, for the overview of this module and its data see Scholz, Jutz, Pammett, and Hadler, 2017). ISSP is one of the significant cross-national collaboration programmes that is focused on diverse topics relevant to social sciences, including the role of government, citizenship, social inequality, work orientations, environment, national identity etc. (see further: www.issp.org). All collected data and documentation is available through the GESIS data archive (see www.gesis.org/issp/home).

The module on citizenship was started in 2004 and was repeated in 2014. The module of Citizenship II has been implemented in 34 countries. In this article, we analyzed data from 28 countries around the world: Australia, Austria, Belgium, Chile, Czech Republic, Germany, Denmark, Spain, Finland, France, Great Britain, Georgia, Croatia, India, Iceland, Israel, Lithuania, Netherlands, Norway, Russian Federation, Slovak Republic, Slovenia, Sweden, Turkey, Taiwan, Venezuela, and South Africa. Some countries (Switzerland, Hungary, Japan, South Korea, Philippines, Poland) have not been included due to the fact that some of the questions used in our analyses were not asked or asked in a way that did not provide sufficient variation of answers to be included into analyses ${ }^{1}$.

\section{Table 1. Ethno-racial composition of the sample}

\begin{tabular}{|c|c|c|c|c|c|}
\hline \multirow[b]{2}{*}{ COUNTRY } & \multicolumn{2}{|c|}{$\begin{array}{l}\text { ETHNO-RACIAL GROUPS } \\
\text { REPRESENTED IN CRITICAL } \\
\text { POLITICAL POSITIONS }\end{array}$} & \multicolumn{2}{|c|}{ OTHER ETHNO-RACIAL GROUPS } & \multirow[t]{2}{*}{$\mathrm{N}$} \\
\hline & $\begin{array}{l}\text { REPRESENTATIVES IN THE } \\
\text { SAMPLE }\end{array}$ & $\%$ & $\begin{array}{c}\text { REPRESENTATIVES IN THE } \\
\text { SAMPLE }\end{array}$ & $\%$ & \\
\hline Australia & $\begin{array}{l}\text { Respondent or parents born in } \\
\text { Australia or English speaking } \\
\text { country }\end{array}$ & 74.9 & $\begin{array}{l}\text { Respondent or parents born } \\
\text { elsewhere or indigenous }\end{array}$ & 25.1 & 1393 \\
\hline Austria & Both parents born in Austria & 83.8 & One or both parents born abroad & 16.2 & 1033 \\
\hline Belgium $^{2}$ & Flemish & 58.7 & Walloon & 41.3 & 1198 \\
\hline Chile & Not indigenous & 91.9 & Indigenous & 8.1 & 1389 \\
\hline
\end{tabular}

\footnotetext{
${ }^{1}$ Also, the sample of United States was eliminated from the analysis as Barack Obama was the president of the US at the time of the survey and distinction between the "minority" and the "majority" in the country became blurred.
}

2 Only Flemings and Walloons kept in the sample. 


\begin{tabular}{|c|c|c|c|c|c|}
\hline \multirow[b]{2}{*}{ COUNTRY } & \multicolumn{2}{|c|}{$\begin{array}{l}\text { ETHNO-RACIAL GROUPS } \\
\text { REPRESENTED IN CRITICAL } \\
\text { POLITICAL POSITIONS }\end{array}$} & \multicolumn{2}{|c|}{ OTHER ETHNO-RACIAL GROUPS } & \multirow[t]{2}{*}{$\mathrm{N}$} \\
\hline & $\begin{array}{l}\text { REPRESENTATIVES IN THE } \\
\text { SAMPLE }\end{array}$ & $\%$ & $\begin{array}{c}\text { REPRESENTATIVES IN THE } \\
\text { SAMPLE }\end{array}$ & $\%$ & \\
\hline Czech Republic & Czech & 89.3 & Other & 10.7 & 1530 \\
\hline Germany & German & 90.9 & Other & 9.1 & 1695 \\
\hline Denmark & Danish & 81.9 & Other & 18.1 & 1736 \\
\hline Spain & $\begin{array}{c}\text { Spanish, European, world or } \\
\text { other }\end{array}$ & 88.5 & Catalan, Basque or immigrant & 11.5 & 1654 \\
\hline Finland & Finnish-speakers & 89.8 & Other & 10.2 & 1495 \\
\hline France & European & 83.1 & Other & 16.9 & 1118 \\
\hline Great Britain & White & 91.3 & Other & 8.7 & 1578 \\
\hline Georgia & Georgian & 87.3 & Other & 12.7 & 1498 \\
\hline Croatia & Croatian & 95.7 & Other & 4.3 & 985 \\
\hline India & Hindu or Sikh upper & 17.0 & Other & 83.0 & 1174 \\
\hline Iceland & Not an ethnic group or minority & 96.9 & Ethnic group or minority & 3.1 & 1350 \\
\hline Israel & Jews & 85.5 & Arabs & 14.5 & 1204 \\
\hline Lithuania & Lithuanian & 87.6 & Other & 12.4 & 1106 \\
\hline Netherlands & Dutch & 88.0 & Other & 12.0 & 1631 \\
\hline Norway & Norwegian & 94.0 & Other & 6.0 & 1413 \\
\hline Russia & Russian & 83.8 & Other & 16.2 & 1590 \\
\hline \begin{tabular}{|l|} 
Slovak \\
Republic \\
\end{tabular} & Slovakian & 88.5 & Other & 11.5 & 1154 \\
\hline Slovenia & Slovenian & 90.3 & Other & 9.7 & 1008 \\
\hline Sweden & Swedish & 86.1 & Other & 13.9 & 880 \\
\hline Turkey & Turkish & 81.6 & Other & 18.4 & 1481 \\
\hline Taiwan & Hoklo or Hakka & 50.8 & Mainlander, aborigine or other & 49.2 & 1875 \\
\hline Venezuela & White, mestizo or indigenous & 61.1 & Mulatto or black & 38.9 & 1005 \\
\hline South Africa & Black African & 56.4 & $\begin{array}{l}\text { White, coloured, Indian, Asian } \\
\text { or other }\end{array}$ & 43.6 & 3124 \\
\hline
\end{tabular}

Source: ISSP Research Group (2016), authors' own calculations.

As to our dependent variable measuring trust in government, we used one item from a battery of questions included in the ISSP module on citizenship asking respondents: "To what extent do you agree or disagree with the following statements?" and the first item mentioned: "Most of the time we can trust people in government to do what is right". This item is quite well suited for analyzing ethnoracial differences of political trust as it is detached from personalities and specific institutions and is formulated in general terms. Answer categories on a 5 point scale ranged from "Strongly disagree" (-2) to "Strongly agree" (2).

Somewhat more challenging was the construction of our main independent variable belonging to different ethno-racial groups. We needed to differentiate respondents into two groups: the ones belonging to ethno-racial groups represented in important political positions and the ones belonging to ethno-racial groups not represented in those positions. Usually, the dividing line was drawn between the titular nationality (or race) and all the others, as representatives of the former usually take the most important positions in government. However, this distinction was not always easy to make due to two factors. First, in ethnically and/or racially heterogeneous countries, compromises had to be made, and some of the groups 'took on board' rather distinct groups. 
The distinction between groups 'in power' and 'not in power' was decisive in these cases. Second, the actual measurement of belonging to ethno-racial groups was quite different among countries in the ISSP survey. Some countries asked about the racial background (Great Britain, South Africa, Venezuela) and others about ethnic background (majority of countries), some countries asked about ancestry (Australia, Austria, the USA), and some others opted out altogether (Switzerland, South Korea, Hungary etc.). The full composition of the sample and the rules for dividing respondents into the two groups in all the countries included in our analysis are provided in Table 1.

As to our control variables for the relation between ethno-racial differences and trust in government, we use three indicators: country scores on all six of Hofstede's cultural dimensions, a country's Gini index scores and annual growth of GDP. Following Hofstede (2011, p. 3), culture is defined as the collective programming of the mind that distinguishes the members of one group or category of people from others. In this context, Hofstede distinguishes six dimensions of culture (2011) that we use as separate independent variables.

Power Distance measures inequality perceived and determined by society itself, defined from below, not from above. Power distance is defined as "the extent to which the less powerful members of organizations and institutions accept and expect that power is distributed unequally" (Hofstede, 2011 p. 9). In societies with small power distance, power is perceived as "subject to criteria of good and evil", such societies have pluralist governments based on a majority vote that rarely experiences political corruption. Societies with large power distance understand power as a basic determinant of good and evil, and its' legitimacy is considered irrelevant. Large power societies have autocratic governments changed by revolutions, experience frequent political scandals, political scandals are covered up. According to Hofstede (2010, 2011), the Power Distance Index is usually higher in Eastern European, Latin, Asian and African countries than in Western European countries.

Uncertainty Avoidance index measures society's tolerance for uncertainty and indicates to what extent different societies feel comfortable or uncomfortable with ambiguous situations. Ambiguous and unstructured circumstances include innovations, surprises, different from usual routine situations. Weak uncertainty societies demonstrate high tolerance towards deviant persons and ideas, dislike written or unwritten rules, citizens feel and are seen as competent towards political authorities. Strong uncertainty avoidance societies are intolerant to deviant persons and ideas thinking that what is different might be dangerous, feel an emotional need for rules though not always obey them; in politics, citizens are seen as incompetent towards authorities. Hofstede $(2010,2011)$ notices that this index tend to be higher in Eastern and Central Europe, in Latin countries, Germanspeaking countries and lower in English speaking countries, Nordic and Chinese cultures.

Individualism vs Collectivism measure indicates how much individuals are integrated into social groups. Individualist cultures demonstrate "I" consciousness; meanwhile, collectivist societies have "we" consciousness. Individualist societies others classify as individuals and collectivist cultures others see as "in-group" or "out-group" elements as people are born into extended families which require their loyalty and protect them. Following Hofstede (2010, 2011), individualism tends to dominate in Western countries, while collectivism prevails in less developed and Eastern countries.

Masculinity vs Femininity as a cultural characteristic refers to distribution between values that are considered as masculine and feminine. The assertive pole is called "masculine", and the modest, caring pole is called "feminine" (Hofstede, 2011). In feminine cultures dominates sympathy for the weak; many women are elected in political positions, there is minimum emotional and social role differentiation between genders. Masculine societies experience maximum emotional and social role differentiation between genders, and few women are in elected political positions; religion focuses on God, not humans. According to Hofstede $(2010,2011)$ masculinity is high in German-speaking countries, some Latin countries, moderately high in English speaking Western countries and is low in Nordic countries and the Netherlands as well as in France, Spain, Portugal, Chile, Korea and Thailand. 
Long term vs Short-term orientation is the measure related to cultural memory and history. Countries with short-term orientation suppose from their citizens to be proud of one's country, demonstrate personal steadiness and stability thinking that a good person is always the same. Long-term oriented societies think that a good person adapts to circumstances, are trying to learn from other countries. Hofstede (2010, 2011), long-term oriented countries are East Asian countries and Eastern and Central Europe, short-term oriented are USA, Australia, Latina American, African and Muslim countries.

Indulgence vs Restraint is the newest dimension and indicates how much social and cultural norms in society controls gratification of basic needs and desires. Cultures of indulgence demonstrate high percentage of citizens who identify themselves as very happy, meanwhile in restrained societies have fewer very happy people. Indulgent cultures demonstrate a higher percentage of obsessing people (in countries with enough food), lenient sexual norms (in wealthy countries), higher birthrates (in countries with educated populations). Meanwhile, in restrained cultures, nevertheless, a country is wealthy, has an educated population and enough food, there are lower birthrates, fewer obese people, stricter sexual norms. Following Hofstede (2010, 2011), indulgence is typical to South and North America, Western Europe and Sub-Sahara Africa, meanwhile, restraint prevails in Eastern Europe, Asia and Muslim countries.

The country scores on all six of Hofstede's cultural dimensions were taken from his official website (see www.hofstede-insights.com/product/compare-countries).

As a measure of socio-economic inequality, we used the Gini index, which measures relative income inequality or the extent to which the distribution of income (or, in some cases, consumption expenditure) among individuals or households within an economy deviates from a perfectly equal distribution. A Lorenz curve plots the cumulative percentages of total income received against the cumulative number of recipients, starting with the poorest individual or household. The Gini index measures the area between the Lorenz curve and a hypothetical line of absolute equality, expressed as a percentage of the maximum area under the line. Thus a Gini index of 0 represents perfect equality, while an index of 100 implies perfect inequality. The country Gini index scores were taken from the World Bank World Development Indicators (WDI) database (available at: https://data.worldbank.org/indicator/NY.GDP.PCAP.CD). Data are based on primary household survey data obtained from government statistical agencies and World Bank country departments ${ }^{3}$. Gini index in the year the survey was started in the country was used, except in Australia (latest data available for 2010), Chile (2013), Germany (2013), Iceland (2014), India (2011), Israel (2012), Philippines (2012), South Africa (2014) and United States (2013). Since data for Taiwan is unavailable in the WDI database, it was taken from the CIA World Factbook (see www.cia.gov/library/publications/the-world-factbook/fields/2172.html, 2014 est.). Finally, data on the Gini index for Venezuela in the WBI is available only till 2006. Therefore, the value of the Gini index was taken from the CIA World Factbook, too (see www.cia.gov/library/publications/the-worldfactbook/fields/2172.html, 2011 est.).

As a measure of economic hardship (prosperity), we used the annual growth of GDP, which represents the annual percentage growth rate of GDP at market prices based on constant local currency. The measure was taken from the World Bank World Development Indicators (WDI) database (available at: https://data.worldbank.org/indicator/NY.GDP.MKTP.KD.ZG). Growths aggregates in the database are based on constant 2010 U.S. dollars. GDP in the database is calculated as the sum of gross value added by all resident producers in the economy plus any product taxes and minus any subsidies not included in the value of the products. It is calculated without making deductions for depreciation of fabricated assets or for depletion and degradation of natural resources. Annual GDP growth the year before the survey was started in the country was used for the analysis. Again, since data for Taiwan is unavailable in the WDI database, it was calculated from Taiwan's

\footnotetext{
${ }^{3}$ For more information and methodology, see http://iresearch.worldbank.org/PovcalNet/index.htm.
} 
Nominal GDP figures available at the CEIC macroeconomic indicators database (available at: www.ceicdata.com/en/indicator/taiwan/nominal-gdp).

The methods of statistical analysis used were rather simple ones. We performed a nonparametric paired two-sample Mann-Whitney-Wilcoxon signed-rank test with continuity correction for establishing differences of trust between ethno-racial groups. Moreover, we performed linear regression analysis in order to investigate which factors are related to differences of trust in government between dominant and minority ethno-racial groups.

\section{Results}

First, we calculated means of trust in government for dominant and minority ethno-racial groups in separate countries included in the sample (see Table 2) and performed a non-parametric paired two-sample Mann-Whitney-Wilcoxon signed-rank test with continuity correction to check whether differences of means are statistically significant across countries.

The results of the analysis show that there does exist a statistically significant difference $(\mathrm{V}=294$, p-value $=0.039)$ and, thus, we have a confirmation for our first hypothesis. In general, dominant ethno-racial groups tend to trust the government more (country mean: -0.201 and median: -0.162 ) than minority groups (country mean: -0.283 and median: -0.245 ). However, there is quite a large group of countries where the opposite is true (for example, Finland, Great Britain, Austria, Germany, France or Lithuania). It is an interesting result and requires further attention in academic literature. Namely, why ethno-racial difference of trust in government is negative in some countries and positive in others. Another fascinating stream of research could study why trust in government is higher among the minority groups in some countries.

Furthermore, we explored the influence of cultural and socio-economic factors on country level ethno-racial differences of trust in government. Regression analysis ${ }^{4}$ showed (see Table 3 ) that both cultural and socio-economic factors might be associated with ethno-racial differences of trust in government. Namely, among cultural dimensions power distance appeared to be positively related to differences of trust. This means that in countries with higher scores on power distance ethno-racial minorities trust the government less. However, other dimensions of culture are not related to the ethno-racial differences of political trust. This might indicate that not the extremity but the substance of culture is a causal factor of these differences.

Table 2. Differences of trust in government between dominant and minority ethno-racial groups

\begin{tabular}{|l|l|l|l|}
\hline \multicolumn{1}{|c|}{ COUNTRY } & $\begin{array}{c}\text { TRUST IN THE GOVERNMENT } \\
\text { OF DOMINANT ETHNO- } \\
\text { RACIAL GROUPS }\end{array}$ & $\begin{array}{c}\text { TRUST IN THE } \\
\text { GOVERNMENT OF } \\
\text { MINORITY GROUPS }\end{array}$ & DIFFERENCE \\
\hline Australia & -0.046 & 0.000 & -0.046 \\
\hline Austria & -0.227 & -0.043 & -0.184 \\
\hline Belgium & -0.160 & -0.403 & 0.243 \\
\hline Chile & -0.386 & -0.374 & -0.012 \\
\hline Croatia & -0.775 & -0.810 & 0.035 \\
\hline Czech Republic & -0.571 & -0.594 & 0.023 \\
\hline Denmark & 0.205 & 0.016 & 0.189 \\
\hline Finland & -0.047 & 0.238 & -0.285 \\
\hline France & -0.581 & -0.470 & -0.112 \\
\hline Georgia & 0.097 & 0.095 & 0.002 \\
\hline Germany & -0.284 & -0.125 & -0.159 \\
\hline Great Britain & -0.226 & -0.033 & -0.193 \\
\hline
\end{tabular}

\footnotetext{
${ }^{4}$ We ran a separate regression model with Indulgence variable excluded, as the score on this dimension of culture is not available for Israel. Two regression models constituted a robustness check controlling not only for smaller sample size but also for inclusion of different variables. Georgia was excluded from both analyses, as the data on cultural dimensions are unavailable for this country
} 


\begin{tabular}{|l|l|l|l|}
\hline \multicolumn{1}{|c|}{ COUNTRY } & $\begin{array}{c}\text { TRUST IN THE GOVERNMENT } \\
\text { OF DOMINANT ETHNO- } \\
\text { RACIAL GROUPS }\end{array}$ & $\begin{array}{c}\text { TRUST IN THE } \\
\text { GOVERNMENT OF } \\
\text { MINORITY GROUPS }\end{array}$ & DIFFERENCE \\
\hline Iceland & -0.164 & -0.429 & 0.265 \\
\hline India & 0.245 & 0.017 & 0.228 \\
\hline Israel & -0.062 & -0.064 & -0.002 \\
\hline Lithuania & -0.694 & -0.598 & -0.095 \\
\hline Netherlands & 0.020 & -0.096 & 0.116 \\
\hline Norway & 0.151 & 0.118 & 0.033 \\
\hline Russia & 0.237 & 0.138 & 0.099 \\
\hline Slovak Republic & -0.560 & -0.789 & 0.228 \\
\hline Slovenia & -0.840 & -0.903 & 0.063 \\
\hline South Africa & 0.304 & -0.413 & 0.717 \\
\hline Spain & -0.664 & -0.783 & 0.119 \\
\hline Sweden & 0.353 & 0.114 & 0.239 \\
\hline Taiwan & -0.638 & -0.655 & 0.017 \\
\hline Turkey & -0.030 & -0.269 & 0.239 \\
\hline Venezuela & -0.119 & -0.221 & 0.102 \\
\hline
\end{tabular}

Note: Positive values mean that dominant ethno-racial groups' trust government more than minority groups

Table 3. Linear regression models of explanatory factors for ethno-racial differences of trust in government

\begin{tabular}{lrr}
\hline & & \multicolumn{2}{c}{$\begin{array}{r}\text { MODEL WITH INDULGENCE } \\
\text { DIMENSION EXCLUDED }\end{array}$} \\
\cline { 2 - 3 } (Intercept) & $0.075^{*}$ & $0.072 *$ \\
Power distance & $0.122 *$ & $0.103 *$ \\
Individualism & 0.016 & 0.019 \\
Masculinity & -0.052 & -0.041 \\
Uncertainty avoidance & -0.092 & -0.081 \\
Long term orientation & 0.025 & -0.009 \\
Indulgence & 0.044 & -- \\
Annual growth of GDP & -0.008 & -0.012 \\
Gini index & $0.101 * *$ & $0.101 * *$ \\
Adj. $\mathbf{R}^{2}$ & 0.143 & 0.176 \\
$\mathbf{N}$ & 25 & 26 \\
\hline
\end{tabular}

Notes:

Standardized beta coefficients reported.

$* * * \mathrm{p}<0.01 ; * * \mathrm{p}<0.05 ; * \mathrm{p}<0.1$.

As it was already described in the methods section, power distance reflects inequality of power in society. Countries with small power distance are more socio-culturally equal and inclusive, whereas countries that score higher on power distance measures are less equal and inclusive. This seems to be the underlying logic behind the relationship established during the empirical analysis. In socio-culturally unequal societies, minorities usually occupy less privileged positions, and their distrust towards the government reflects their views on the people in government as people external to their "in-group" and consequently less trustworthy.

Another factor related to ethno-racial differences of trust in government appeared to be income inequality as measured by the Gini index. Specifically, the positive direction of the relationship indicates that in countries with higher scores on the Gini index (that is, less economically equal), the trust of ethno-racial minorities in government is significantly less than among the dominant group. 
The other economic factor - the economy dynamics - is not directly related to ethno-racial differences of political trust.

We might already see a trend here. Power distance reflects socio-cultural inequality, and the Gini index measures economic inequality. Therefore, both indices related to inequality in society are significant determinants of ethno-racial differences of trust in government. Thus, we might conclude that the political and economic inequality existing in societies are responsible for the differing trust in government among ethno-racial groups.

\section{Conclusion}

The paper has questioned whether ethno-racial diversity and related contextual factors, like cultural and socio-economic institutions, have an impact on differences of trust in government and which factors are the most important. Many theorists emphasize that, in general, trust is embedded in encapsulated interests and capabilities - a belief of goodwill and trustworthiness. In this context, familiarity and ethno-racial background followed by socio-economic position may play a relevant role in generating trust in government.

The research results show that ethno-racially based particularized trust is prevalent in many societies, i.e., citizens tend to trust more politicians that are considered to be similar to them and tend to trust less the people in government if they are predominantly from a different ethnic group. Therefore, empirical evidence supports our first hypothesis (H1), which states that ethnic groups not represented in critical political positions tend to trust the people in government less.

Further, this ethno-racially based difference of trust in government is related to the sociocultural settings of a country. At least measured according to Hofstede's conceptualization. The data indicate that the cultural dimension reflecting power distance affects ethno-racially based differences of trust in government. According to Hofstede (2011), all societies are unequal, but some groups in society feel more unequal than others. This is precisely the feature of societies that have high scores on the power distance dimension. Moreover, our data show that in socio-culturally unequal societies, ethno-racial minorities trust the government less.

Another contextual factor that appeared to impact differences in ethno-racially based trust in government appears to be income inequality. If the income inequality in a country is high, minority groups trust the government less than people from the dominant groups. As it is widely noticed in academic discourse (Uslaner 2000, Putnam 2000, etc.), citizens do not tend to trust if they worry about the future and this distrust increase with the growth of economic inequality. Moreover, income inequality is the key factor that makes different social groups feel unequal. As a matter of fact, ethnoracial minorities are often related to cultural and economic isolation, which implies the domination of particularized trust in government. Interestingly, the data also indicate that although the trust levels as such tend to reflect the economic prosperity of a country, ethno-racially based differences in trust in government do not depend on a country's wealth or economic prosperity.

Overall, these findings give partial support to our second (H2) and third (H3) hypotheses. One of the cultural dimensions (power distance), as conceptualized by Hofstede, and economic inequality moderates the relationship between ethno-racial background and trust in government. In 2000 Uslaner, summarizing a wide range of trust research, it has been observed that citizens "do not tend to feel better about the future until we reverse the trend in economic inequality" (p. 590). Unfortunately, in almost 20 years, this trend has not changed yet.

Finally, we have to draw attention to some limitations of the research presented in this paper. All the analyses of this article have been conducted on the aggregated country level. In this regard, this research differs from other research on institutional trust. Although we acknowledge that trust operates primarily at the individual level, this research shows that macro-factors, be it the cultural or economic characteristic features of a country, might have added value in explaining the variance therein. Therefore, further studies of ethno-racially based differences of trust in government might need to be conducted using multi-level analysis in order to have a more comprehensive and elaborate picture of what exactly explains the variance therein. 


\section{References}

1. Alesina, A. \& La Ferrara, E. (2002). Who trusts others? J. Public Econ. 85:207-34.

2. Ananyev, M. \& Guriev, S. M. (2014). Effect of Income on Trust: Evidence from the 2009 Crisis in Russia. Available at SSRN: http://ssrn.com/abstract=2542001

3. Anderson, J. E. (2015). The Economic Crisis and its Impact on Trust in Institutions in Transition Countries. Available SSRN: https://ssrn.com/abstract=2652265 or http://dx.doi.org/10.2139/ssrn.2652265

4. Barth, J. (2016). Trust in Government: An Investigation, NCUR.

5. Beugelsdijk, S. et al. (2004). Entrepreneurial attitude and economic growth: A cross-section of 54 regions 38: 199, 2004. https://doi.org/10.1007/s00168-004-0192-y

6. Bjørnskov, Ch. (2012). How Does Social Trust Affect Economic Growth? Southern Economic Journal, 78 (4), p.1346-1368

7. Brüeckner, M., Chong, A., \& Gradstein, M. (2015). Does Economic Prosperity Breed Trust? World Economic Forum

8. Chanley, V. A., Rudolph, T. J. \& Rahn, W. (2000). The Origins and Consequences of Public Trust in Government: A Time Series Analysis" Public Opinion Quarterly 64 pp. 239-240.

9. Coleman, JS. (1990). Foundations of Social Theory. Cambridge, MA: Belknap/Harvardisẹpi, 1990

10. De Vries, M.S. and Sobis, I. (2018). Trust in the Local Administration: A Comparative Study between Capitals and Non-Capital Cities in Europe. NISPAcee Journal of Public Administration and Policy, Volume 11: Issue 1 Available at: https://doi.org/10.2478/nispa-2018-0009

11. Dunn, J. (2000). Trust and Political Agency. In: Gambetta, Diego (ed.) Trust: Making and Breaking Cooperative Relations, electronic edition, University of Oxford, chapter 5, pp. 73-93, 2000 <http://www.sociology.ox.ac.uk/papers/dunn73- 93.pdf>.

12. Fukuyama, F. (2001). Social Capital, civil society and development. Third World Quarterly, Vol 22:1, pp. 7-20

13. Guiso,m L. et al. (2004). The Role of Social Capital in Financial Development. American Economic Review, 94 (3): 526-556

14. Hardin, R. (2000). The Public Trust. In: S. J. Pharr, R.D. Putnam (eds.). Disaffected Democracies: What's Troubling the Trilateral Countries? New Jersey: Princeton University Press

15. Hardin, R. (2002). Trust and Trustworthiness. New York: Russell Sage

16. Hofstede, G. (2011). Dimensionalizing Cultures: The Hofstede Model in Context. Online Readings in Psychology and Culture, 2(1), Available at: https://doi.org/10.9707/2307-0919.1014

17. Hofstede, G. et al. (1984). Hofstede's Culture Dimensions. Journal of Cross-cultural psychology, 15 (4) P.417433

18. ISSP Research Group (2016). International Social Survey Programme: Citizenship II - ISSP 2014. GESIS Data Archive, Cologne. ZA6670 Data file Version 2.0.0, https://doi.org/10.4232/1.12590

19. Jackson, J. Bradford, B. et al. (2011). Developing European indicators of trust in justice. European Journal of Criminology 8 (4)

20. Jackson, J. Hough, M. et al. (2011). Trust in Justice: Topline Results from Round 5 of the European Social Survey, 2011

21. Knack, S. \& Zak, P. J. (2002). Building Trust: Public Policy, Interpersonal Trust, and Economic Development. Available at SSRN: https://ssrn.com/abstract=304640 or http://dx.doi.org/10.2139/ssrn.304640

22. Kroknes, V. F., Jakobsen, T. G. \& Grønning, L-M. (2016). Economic Performance and Political Trust: The impact of the financial crisis on European citizens, European Societies, 17:5, 700-723, 2016 Available at: DOI: $10.1080 / 14616696.2015 .1124902$

23. Kucharska, W. (2017). Relationships between Trust and Collaborative Culture in The Context of Tacit Knowledge Sharing. Journal of Entrepreneurship, Management and Innovation 13(2017):61-78. Available at: DOI: 10.7341/20171344

24. Maloy, J. S. (2009). Two concepts of trust. The Journal of Politics, Vol.71, No. 2, pp. 492-505

25. March, G. J. \& Olsen, P. J. (2009). The logic of appropriateness. In: Goodin R.E, Moran M., Rein M. (eds.) The Oxford Handbook of Public Policy

26. Mishler, W. \& Rose, R. (1997). Trust, Distrust and Skepticism: Popular Evaluations of Civil and Political Institutions in Post-Communist Societies// The Journal of Politics, Vol. 59, No. 2. May p. 418-451.

27. Nannicini, T. et al. (2012). Social Capital and Political Accountability. Available at http://tommasonannicini.eu/media/works/files/accountability_AEJ_FINAL_july2012.pdf

28. Newton, K. \& Norris, P. (2000). Confidence in Public Institutions: Faith, Culture, or Performance? In: S.J. Pharr, R.D. Putnam (eds.). Disaffected Democracies: What's Troubling the Trilateral Countries? New Jersey: Princeton University Press, 52-73.

29. Patterson, O. (1999). Liberty against the democratic state: on the historical and contemporary sources of American distrust. In Democracy and Trust, ed. M Warren, pp. 151-207. Cambridge, UK: Cambridge Univ. Press

30. Paxton, P. (1999). Is social capital declining in the United States? A multiple indicator assessment. Am. J. Sociol. 105(1):88-127.

31. Putnam, R. D. (1995). Bowling alone: America's declining social capital. J. Democr. 6: 65-78, 1995 
32. Roth, F., Gros, D., \& Nowak-Lehmann D. F. (2014). Crisis and citizens' trust in the European Central Bank-panel data evidence for the euro area, 1999-2012. Journal of European Integration, 36(3), pp. 303-320.

33. Scholz, E., Jutz R., Pammett J. H. \& Hadler M. (2017). ISSP and the ISSP 2014 Citizenship II Module: An Introduction. International Journal of Sociology, 47:1,19, DOI: 10.1080/00207659.2017.1264825

34. Seligman, A. B. (2000). The Problem of Trust. Princeton: Princeton University Press

35. Smith, S. S. (2010). Race and trust. Annual Review of Sociology 36, p. 453-475

36. Smith, T.W. (1997). Factors relating to misanthropy in contemporary American society. Soc. Sci. Res. 26:170-96

37. Sztompka, P. (1999). Trust: A Sociological Theory. Cambridge, UK: Cambridge Univ. Pressísẹp:

38. Uslaner, E. M. (2000). Producing and Consuming Trust. Political Science Quarterly (115), pp. 569-590

39. Van de Walle, S., Van Roosbroek, S. \& Bouckaert, G. (2008). Trust in the public sector: is the any evidence for a long-term decline? International Review of Administrative Science

40. Whiteley, P. (2000). Economic Growth and Social Capital. Political Studies, Volume: 48 issue: 3, page(s): $443-466$

41. Williams, B. (1988). Formal structures and social reality. In Trust: Making and Breaking Cooperative Relations, ed. D Gambetta, pp. 3-13. Oxford: Basil Blackwell

42. Wroe, A. ( 2015). Economic Insecurity and Political Trust in the United States. American Politics research, p. 131163

43. Yamagishi, T. (2001). Trust as a form of social intelligence. In Trust in Society, ed. KS Cook, pp. 121-47. New York: Russell Sage Found

44. Zak, P. J., Knack, S. (2001). Trust and Growth. The Economic Journal 111 (470), 295-321.

Eglè Vaidelytė, Eglè Butkevičienė, Vaidas Morkevičius, Michiel S. de Vries

\section{Panašumas ir pasitikẻjimas: etniniai-rasiniai skirtumai kaip pasitikẻjimo valdžia veiksnys}

\section{Anotacija}

Straipsnyje analizuojamas bendrasis pasitikèjimas valdžios institucijomis ir šio pasitikèjimo skirtumai tarp skirtingų etninių grupių visuomeneje. Pastebima, kad įvairūs teoriniai požiūriai ir empriniai tyrimai institucini pasitikejjimą dažniausiai aiškina ir tyrinèja individualiame lygmenyje per subjektų, kuriais pasitikima, savybes ir intencijas, siekiant nustatyti, ar pasitikinčiojo ir to, kuriuo pasitikima, individualios charakteristikos turi aiškinamosios galios. Tuo tarpu šiame straipsnyje pasitikejjimas valdžios institucijomis analizuojamas makro (šalies) lygmenyje. Remiantis 29 šalių lyginamuoju tyrimu, nustatyta, kad egzistuoja reikšmingi skirtumai tarp etninių grupių pasitikejjimo valdžios institucijomis, kuriuos lemia pajamų nelygybè, ir šalyje vyraujančios kultūrinès orientacijos (,galios distancija“, išmatuota pagal Hofstede kultūrinių dimensijų modelį). Šis rezultatas patvirtina, kad aiškinant pasitikejjimą valdžios institucijomis ne mažiau svarbūs yra ir makro lygmens kintamieji, kurie papildo individualaus lygmens kintamujų įtaką.

Egle Vaidelyte, associate professor and head of the Committee of Political Science, Sociology and Public Governance Study Program at the Faculty of Social Sciences, Arts and Humanities, Kaunas University of Technology

E-mail: egle.vaidelyte@ktu.lt

Egle Butkeviciene, full professor and vice-dean for research at the Faculty of Social Sciences, Arts and Humanities, Kaunas University of Technology

E-mail: egle.butkeviciene@ktu.lt

Vaidas Morkevicius, senior researcher at the Faculty of Social Sciences, Arts and Humanities, Kaunas University of Technology

E-mail: vaidas.morkevicius@ktu.lt 
Michiel S de Vries, full professor and chair of the Department of Public Administration at the Radboud University Nijmegen, the Netherlands and distinguished professor at Kaunas Technological University, Lithuania

E-mail: $\underline{\text { m.devries@ fm.ru.nl }}$

Egle Vaidelyte, docentė, Politikos mokslų, Sociologijos ir Viešojo valdymo studijų krypčių programų komiteto vadovè,Kauno technologijos universitetas

El. paštas: egle.vaidelyte@ktu.lt

Egle Butkeviciene, profesorė, Socialinių, humanitarinių mokslų ir menų fakulteto mokslo prodekanė, Kauno technologijos universitetas

E-mail: egle.butkeviciene@ktu.lt

Vaidas Morkevicius, Socialinių, humanitarinių mokslų ir menų fakulteto vyriausias mokslo darbuotojas, Kauno technologijos universitetas

E-mail: vaidas.morkevicius@ktu.lt

Michiel $S$ de Vries, profesorius, Nijmegen Radboud universiteto (Nyderlandai) Viešojo administravimo katedros vedejas, Kauno Technologijos universiteto kviestinis profesorius E-mail: m.devries@fm.ru.nl 